\title{
ANTIBACTERIAL, ANTIVIRAL AND CYTOTOXIC ACTIVITIES OF RHYNCHOPHORUS FERRUGINEUS (COLEOPTERA: DRYOPHTHORIDAE) AND SPODOPTERA LITTORALIS (LEPIDOPTERA: NOCTUIDAE) LARVAL EXTRACTS
}

\author{
By
}

MUSTAFA I. HASSAN ${ }^{1}$, AHMED Z.I. SHEHATA ${ }^{1 *}$, MOHAMED M.S. FARAG ${ }^{2}$, AMR M. SHEHAB ${ }^{2}$, MOHAMED T.M. MANSOUR ${ }^{3}$, AHMED N.G. ABDEL-AZIZ ${ }^{1}$ Department of Zoology ${ }^{1}$, and Department of Botany and Microbiology, Faculty of Science, Al-Azhar University, Nasr City, Cairo, and Children's Cancer Hospital $57357^{3}$, Cairo, Egypt ( ${ }^{*}$ Correspondence:ahmedzeinhom00@gmail.com)

\section{Abstract}

The present study dealt with evaluating the effect of different crude extracts from the larvae of palm weevil, Rhynchophorus ferrugineus and cotton leaf worm, Spodoptera littoralis on different pathogenic strains of bacteria and viruses. The results revealed that, ethyl acetate extracts of $R$. ferrugineus and $S$. littoralis larvae were more effective against different pathogenic bacterial strains tested than petroleum ether, chloroform, methanol and ethanol extract. Also, The MICs' determination showed that all different extracts of $R$. ferrugineus and $S$. littoralis larvae were active against tested bacterial strains. Minimum Inhibitory Concentration (MIC) values were ranged from 25 to $6.25 \mathrm{mg} / \mathrm{ml}$ depended on tested species. Ethyl acetate extract from $R$. ferrugineus and $S$. littoralis larvae exhibited antiviral activity against hepatitis A virus (HAV) and Herpes simplex virus (HSV-1) cell lines at $625 \& 312.5 \mathrm{mg} / \mathrm{ml}$. Ethyl acetate extract from $R$. ferrugineus and S. littoralis larvae recorded $5.19 \& 4.07 \%$ antiviral activity against HAV at $625 \& 312.5 \mathrm{mg} / \mathrm{ml}$, respectively; while, antiviral activity percentage was $12.42 \& 26.17$ at 625 and $312.5 \mathrm{mg} / \mathrm{ml}$, respectively against HSV-1. Tested extracts exhibited no antiviral activity against Coxsackie B virus (Cox B4) cell lines. Crude extracts of $R$. ferrugineus \& S. littoralis were not cytotoxic to Vero (CCL-81) cells at 312.5 and/or $625 \mu \mathrm{g} / \mathrm{ml}$.

Keys words: Antibacterial activity, Rhynchophorus ferrugineus, S. littoralis.

\section{Introduction}

The discovery of penicillin, antibiotics were instrumental in treating infectious diseases. But, emerging antibiotic multi-resistance coincided with a nearly exhausted drug pipeline was a major concern for future of therapy of infections (Netzker et al, 2018). But antimicrobial resistance was a major global issue, the rate of emergence of antimicrobial resistance has superseded the rate of discovery and introduction of new effective drugs (The et al, 2017). Antimicrobial peptides of insects play an important role in innate immune systems and host defense mechanisms attracted attention as a novel class of antibiotics, in particular for antibiotic resistant pathogens, because of their action mechanism of non- selective interaction with cell surface membranes of microbes (Hancock and Rozek, 2002; Zasloff 2002;
Boman 2003; Bulet et al, 2004), insect peptides/polypeptides a broad spectrum of activity against Gram-positive \& negative bacteria and fungi (Hoffmann et al, 1996). Antibacterial proteins were isolated from insects (Cociancich et al, 1994) of five main groups (Hultmark 1993): cecro-pins, insect defensins, attacin-like (glycine-rich) proteins, proline-rich peptides and lysozymes. But, only a few number of antifungal peptides/polypeptides were reported from insects; drosomycin (Fehlbaum et al, 1994), metchiniko-win, cecropin A \& B from Hyalophora cecropia (Levashina et al, 1995) and heliomicin from Hellothis virescens (Lamberty et al, 1999).

The present study aimed to evaluate crude extracts activity from larvae of palm weevil, Rhynchophorus ferrugineus and cotton leaf worm, Spodoptera littoralis against some pathogenic strains of bacteria and viruses. 


\section{Materials and Methods}

Insects used: Last instar larvae of Rhynchophorus ferrugineus (Coleoptera: Dryophthoridae) and Spodoptera littoralis (Lepidoptera: Noctuidae) were collected from Ismailia and Beheira Governorates and maintained for several generations in Entomology Insectary, Animal House, Department of Zoology (Shahina et al, 2009; El-Sheikh and Aamir, 2011).

Extraction and sample preparation: The larvae were washed with $80 \%$ ethanol as a disinfectant for three seconds, then rinsed with deionized water and excess water was removed by filter paper. Fifty grams of each insect species were thoroughly homogenized in $50 \mathrm{ml}$ of $40 \mathrm{mM}$ tris- $\mathrm{HCl}(\mathrm{pH} \mathrm{7.4)}$. The homogenate was centrifuged at 10,000rpm for $30 \mathrm{~min}$ at $4{ }^{\circ} \mathrm{C}$ and supernatant was used as buffer extract. The residue was soaked in pure methanol and centrifuged again. The supernatant was the methanolic extract. The residue was soaked in ethanol $70 \%$ and centrifuged again. The supernatant was the ethanolic $70 \%$ extract. The residue was soaked in petroleum ether and centrifuged again. The supernatant was the petroleum ether extract. The residue was soaked in ethyl acetate and centrifuged again. The supernatant was the ethyl acetate extract. Lastly, residue was soaked in chloroform and centrifuged to have the chloroform extract. All extracts were dried by evaporation and tested antimicrobial activity (Meylears et al, 2002).

Antimicrobial bioassay: Four pathogenic organisms were used for antimicrobial assay; Bacillus subtilis and Staphylococcus aureus as Gram-positive bacterial strains, and Escherichia coli \& Enterobacter faecalis were used as Gram-negative strains. Antimicrobial assay was broadly based on the well diffusion and Microdilution methods at Mycology and Biotechnology Antimicrobial Department, Faculty of Science.

Evaluation of antibacterial activity (Well diffusion method): Microbial growth inhibition was assayed using agar well diffusion method (Valgas et al, 2007).
Minimum inhibitory con-centration (MIC) by microdilution method: MIC was determined by broth microdilution method using 96-well micro-plates (Irith et al, 2008).

Antiviral assay (MTT assay protocol): A 10,000 cells in $200 \mu 1$ media per well were plated in a 96 well plate. Three wells were leaved empty for blank controls. Cells were incubated $\left(37^{\circ} \mathrm{C}, 5 \% \mathrm{CO}_{2}\right)$ overnight to allow cells to attach to wells. Non-lethal dilution of tested sample and virus suspension were incubated for an hour (volume 1:1 v/v). A $100 \mu 1$ was added from viral/ sample suspension and placed on a shaking table, 150 rpm for 5 minutes. Cells were incubated $\left(37^{\circ} \mathrm{C}, 5 \% \mathrm{CO}_{2}\right)$ for 1 - days to allow the virus to take effect. Two $\mathrm{ml}$ or more of MTT solution per 96 well plated at $5 \mathrm{mg} / \mathrm{ml}$ in PBS. A $20 \mu 1$ of MTT solution was added to each well and placed on a shaking table, 150 rpm for 5 minutes, to thoroughly mix the MTT into the media. The wells were incubated $\left(37 \mathrm{C}, 5 \% \mathrm{CO}_{2}\right)$ for $1-5$ hours to allow the MTT to be metabolized. The media was dumped off. (Dry plate on paper towels to remove residue if necessary. formazan resuspend (MTT metabolic product) in $200 \mu \mathrm{l}$ DMSO and placed on a shaker, 150rpm for 5 minutes, to thoroughly mix the formazan into the solvent. Optical density was read at $560 \mathrm{~nm}$ and subtracts background at $620 \mathrm{~nm}$, which directly correlated with cell quantity.

Determination of samples cytotoxicity on VERO cell using MTT assay: A $100 \mathrm{mg}$ of tested sample was dissolved in $1 \mathrm{ml}$ DMSO. Growth medium was decanted from 96 well micro titer plates after confluent sheet of VERO cell was formed; cell monolayer was washed twice with wash media. Double-fold dilutions of samples were made in MEM. A $0.1 \mathrm{ml}$ of each dilution was tested starting from $5 \mathrm{mg} / \mathrm{ml}$ in different wells leaving 3 wells as control with maintenance medium. Plate was incubated at $37^{\circ} \mathrm{C}$ and examined frequently for up to 2 days. Cells were checked for any physical signs of toxicity, e.g. partial or complete loss of monolayer, rounding, shrinkage, or cell granulation. 
MTT solution was prepared $(5 \mathrm{mg} / \mathrm{ml}$ in PBS, BIO Basic Canada Inc.). A 20 $\mu 1$ MTT solution were added to each well and placed on a shaker, $150 \mathrm{rpm}$ for 5 minutes, to thoroughly mix the MTT into media and incubated $\left(37^{\circ} \mathrm{C}, 5 \% \mathrm{CO} 2\right)$ for $1-5$ hours to allow the MTT to be metabolized. The media was dumped off (Dry plate on paper towels to remove residue if necessary. Formazan resuspend (MTT metabolic product) in 200ul DMSO and placed on a shaker, 150rpm for 5 minutes, to thoroughly mix the formazan into the solvent. Optical density was read at $560 \mathrm{~nm}$ and subtract background at $620 \mathrm{~nm}$ that directly correlated with cell quantity. Maximum non-toxic concentration [MNTC] of each extract was determined and was used for further biological studies. MNTC for sample ( $R$. ferrugineus) ethyl acetate extract $=625 \mu \mathrm{g} / \mathrm{ml}$. MNTC for sample ( $S$. littoralis) ethyl acetate extract $=312.5 \mu \mathrm{g} / \mathrm{ml}$.

Statistical analysis: Data was done (Armitage, 1974) and analysed by Quattropro for windows program version 2. Microsoft, windows version 7 and graphic were drawn using Harvard Graphics program version 4. Data were assessed by calculating mean, standard deviation and student t-test.

\section{Results}

Antibacterial activity using well diffusion method: For Gram-positive bacteria, methanol extract of $R$. ferrugineus had the highest effect against Bacillus subtilis. The growthinhibition zone was $13.0 \mathrm{~mm}$ vs. $11.4 \mathrm{~mm}$ for Kanamycin antibiotic which used as control. On the other hand, the lowest antibacterial activity against $B$. subtilis was recorded by chloroform extract. The growth-inhibition zone was $10.0 \mathrm{~mm}$. As regards the activity of petroleum ether, ethyl acetate and ethanol extracts against $B$. subtilis, the growthinhibition zones were $11.0,12.0 \& 12.0 \mathrm{~mm}$, respectively. For S. aureus, ethyl acetate extract of $R$. ferrugineus gave the highest effect with $11.0 \mathrm{~mm}$ growth-inhibition zone vs. $11.4 \mathrm{~mm}$ for Kanamycin. Also, ethanol and methanol extracts showed no antibacterial activity against $S$. aureus. Petroleum ether and chloroform extracts activity against $S$. aureus were equal $10.0 \mathrm{~mm}$ (Tab. 1, Fig. 1). On the other hand, chloroform extract of $S p$. littoralis have the highest effect against $B$. subtilis where, growth-inhibition zone was $13.0 \mathrm{~mm}$ vs. $11.4 \mathrm{~mm}$ for Kanamycin antibiotic (control). The lowest antibacterial activity against $B$. subtilis was recorded by petroleum ether \& ethyl acetate extracts, growthinhibition zone was $11.0 \& 11.0 \mathrm{~mm}$, respectively. Activity of ethanol \& methanol extracts against $B$. subtilis recorded 12.0 and $12.0 \mathrm{~mm}$, respectively. For $S$. aureus, the results showed that, ethyl acetate extract of $S p$. littoralis had the highest effect against $S$. aureus with $14.0 \mathrm{~mm}$ growth-inhibition zone vs. $10.3 \mathrm{~mm}$ for Kanamycin. Also, methanol extract showed no antibacterial activity against $S$. aureus (Tab. 2, Fig. 2).

For Gram negative bacteria, ethyl acetate extract of $R$. ferrugineus had the highest effect against Escherichia coli as the growthinhibition zone recorded $10.0 \mathrm{~mm}$ vs. $7.3 \mathrm{~mm}$ for control (Kanamycin). Also, petroleum ether and chloroform extracts recorded 9.0 and $8.0 \mathrm{~mm}$ against $E$. coli, respectively. Ethyl acetate extract of $R$. ferrugineus had the highest effect against Enterobacter faecalis where, the growth-inhibition zone was $11.0 \mathrm{~mm}$ compared with $9.0 \mathrm{~mm}$ for Kanamy$\operatorname{cin}$ and the lowest antibacterial activity against E. faecalis was recorded by ethanol extract where, the growth-inhibition zone was $7.0 \mathrm{~mm}$. Petroleum ether, methanol and chloroform extracts recorded 10.0, 8.0 \& $9.0 \mathrm{~mm}$ inhibition zones against $E$. faecalis, respectively. Ethyl acetate extract of $S$. littoralis have the highest effect against $E$. coli, as growth-inhibition zone recorded $15.0 \mathrm{~mm}$ vs. $11.0 \mathrm{~mm}$ for Kanamycin (control). While, the lowest antibacterial activity against $E$. coli was recorded by petroleum ether extract; the growth-inhibition zone was $7.0 \mathrm{~mm}$. Activity of ethanol, methanol and chloroform extracts against $E$. coli was 14.0, $12.0 \& 11.0 \mathrm{~mm}$, respectively. For E. faecal$i s$, ethyl acetate extract of $S$. littoralis gave the highest effect against E. faecalis. Grow- 
th-inhibition zone was $14.0 \mathrm{~mm}$ compared with $9.0 \mathrm{~mm}$ for Kanamycin. Lowest antibacterial activity against $E$. faecalis was recorded by petroleum ether extract; growth inhibition zone was $8.0 \mathrm{~mm}$. Activity of ethanol, methanol and chloroform extracts against $E$. faecalis was $11.0,10.0 \& 11.0 \mathrm{~mm}$, respectively.

Determination of minimum inhibitory concentration (MIC) by microdilution method: All pervious different crude extracts of $R$. ferrugineus were active against $B$. subtilis, $S$. aureus, E. coli \& E. faecalis showed different antibacterial activity. MIC values were ranged from 25 to $6.25 \mathrm{mg} / \mathrm{ml}$ depending on tested species. Petroleum ether and methanol fractions showed a discrete activity against B. subtilis with MIC at $6.25 \mathrm{mg} / \mathrm{ml}$; whereas only ethanol fraction presented MIC at $25 \mathrm{mg} / \mathrm{ml}$ (Tab. 3 ; 4). Crude extracts of $R$. ferrugineus against $S$. aureus showed that all fractions have a discrete activity with MIC at $6.25 \mathrm{mg} / \mathrm{ml}$ except ethanol fraction presented MIC at $12.5 \mathrm{mg} / \mathrm{ml}$. Ethyl acetate and chloroform fractions showed a discrete activity against $E$. coli with MIC at $6.25 \mathrm{mg} /$ ml. Crude extracts of $R$. ferrugineus against E. faecalis showed that all fractions a discrete activity with MIC at $12.5 \mathrm{mg} / \mathrm{ml}$ except chloroform fraction presented MIC at $25 \mathrm{mg} /$ $\mathrm{ml}$. But, chloroform fraction of $S$. littoralis showed a discrete activity against $B$.

subtilis with MIC at $6.25 \mathrm{mg} / \mathrm{ml}$. Crude extracts of $S$. littoralis against $S$. aureus, ethyl acetate, ethanol and methanol fractions gave a discrete activity with MIC at $6.25 \mathrm{mg} / \mathrm{ml}$. MIC for different crude extracts of S. littoralis against $E$. coli showed that chloroform and ethyl acetate fractions gave a discrete activity against $E$. coli with MIC at $6.25 \mathrm{mg} /$ $\mathrm{ml}$; Petroleum ether fraction was presented MIC at 25mg/ml (Tabs. 5, 6). Petroleum ether fraction of $S$. littoralis gave a discrete activity against $E$. faecalis with MIC at $6.25 \mathrm{mg} / \mathrm{ml}$.

Antiviral activity: Ethyl acetate extract from $R$. ferrugineus and S. littoralis, ethyl acetate extract from both $R$. ferrugineus and $S$. littoralis larvae showed a little antiviral activity against HAV, the activity was 5.2 and $4.1 \%$ for $R$. ferrugineus and S. littoralis, respectively. But, no antiviral activity displayed by tested extracts against Cox B4 virus. Ethyl acetate extract from $R$. ferrugineus and $S$. littoralis larvae gave a good antiviral activity against HSV-1 gave activities $12.5 \& 26.2 \%$ for $R$. ferrugineus and S. littoralis, respectively (Tab. 7).

Cytotoxic assay: Crude extracts of $R$. ferrugineus did not show cytotoxicity against Vero cells when incubated with $312.5 \mu \mathrm{g} / \mathrm{m}$, as the cytotoxicity values were $0.0,0.0,0.1$, $0.0 \& 1.5 \%$ for petroleum ether, ethyl acetate, ethanol, methanol and chloroform, respectively. Crude extracts of $S$. littoralis did not show cytotoxicity against Vero cells when incubated with $312.5 \mu \mathrm{g} / \mathrm{m}$, as the cytotoxicity values were $0.6,1.8,1.5,3.2 \&$ $1.5 \%$ for petroleum ether, ethyl acetate, ethanol, methanol and chloroform, respectively (Fig. 3). Crude extracts of $R$. ferrugineus did not show cytotoxic activity against Vero cells when incubated with $625 \mu \mathrm{g} / \mathrm{ml}$ except for petroleum ether extract, as the cytotoxicity of petroleum ether extract was $40.0 \%$. Crude extracts of $S$. littoralis did not show cytotoxicity against Vero cells when incubated with $625 \mu \mathrm{g} / \mathrm{mL}$ except for ethyl acetate extract; cytotoxicity of ethyl acetate extract the results were $16.0 \%$ (Fig. 4).

Table 1: Growth-inhibition zone of different bacterial strains caused by $R$. ferrugineus larval extracts.

\begin{tabular}{|c|c|c|c|c|c|c|c|}
\hline \multirow{2}{*}{ Bacterial strain } & Gram & \multicolumn{5}{|c|}{ Growth-inhibition zone in mm } & Standard \\
& $+/-$ & Pet. ether & Eth. acetate & Ethanol & Methanol & Chloroform & Kanamycin \\
\hline Bacillus subtilis & $+\mathrm{ve}$ & 11.0 & 12.0 & 12.0 & 13.0 & 10.0 & 11.4 \\
\hline Staphylococcus aureus & $+\mathrm{ve}$ & 10.0 & 11.0 & NA & NA & 10.0 & 10.3 \\
\hline Escherichia coli & $-\mathrm{ve}$ & 9.0 & 10.0 & NA & NA & 8.0 & 7.3 \\
\hline Enterobacter faecalis & -ve & 10.0 & 11.0 & 7.0 & 8.0 & 9.0 & 9.0 \\
\hline
\end{tabular}


Table 2: Growth-inhibition zone of different bacterial strains caused by S. littoralis larval extracts.

\begin{tabular}{|c|c|c|c|c|c|c|c|}
\hline \multirow{2}{*}{$\begin{array}{c}\text { Bacterial } \\
\text { strain }\end{array}$} & Gram & \multicolumn{5}{|c|}{ Growth-inhibition zone in mm } & Standard \\
\cline { 3 - 6 } & $+/-$ & Pet. ether & Eth. acetate & Ethanol & Methanol & Chloroform & Kanamycin \\
\hline B. subtilis & $+\mathrm{ve}$ & 11.0 & 11.0 & 12.0 & 12.0 & 13.0 & 11.4 \\
\hline S. aureus & $+\mathrm{ve}$ & 10.0 & 14.0 & 13.0 & NA & 11.0 & 10.3 \\
\hline E. coli & -ve & 7.0 & 15.0 & 14.0 & 12.0 & 11.0 & 11.0 \\
\hline E. faecalis & -ve & 8.0 & 14.0 & 11.0 & 10.0 & 11.0 & 9.0 \\
\hline
\end{tabular}

Table 3: Minimal Inhibitory Concentrations (MIC) in $\mathrm{mg} / \mathrm{ml}$ of $R$. ferrugineus larval extracts.

\begin{tabular}{|c|c|c|c|c|c|}
\hline Bacterial strain & Petroleum ether & Ethyl acetate & Ethanol & Methanol & Chloroform \\
\hline B. subtilis & 6.25 & 12.5 & 25 & 6.25 & 12.5 \\
\hline S. aureus & 6.25 & 6.25 & 12.5 & 6.25 & 6.25 \\
\hline E. coli & 12.5 & 6.25 & 12.5 & 25 & 6.25 \\
\hline E. faecalis & 12.5 & 12.5 & 12.5 & 12.5 & 25 \\
\hline
\end{tabular}

Table 4: Antibacterial activity indicated by microdilution plate at $480 \mathrm{~nm}$ of $S$. littoralis larval extracts

\begin{tabular}{|c|c|c|c|c|c|c|}
\hline Bacteria strain & Conc. $(\mathrm{mg} / \mathrm{ml})$ & Petroleum ether & Ethyl acetate & Ethanol & Methanol & Chloroform \\
\hline \multirow{4}{*}{ B. subtitles } & Control & $1.75 \pm 0.1$ & $1.33 \pm 0.3$ & $1.05 \pm 0.6$ & $1.62 \pm 0.9$ & $1.49 \pm 0.4$ \\
\cline { 2 - 6 } & 25 & $1.5 \pm 0.1$ & $0.7 \pm 0.1$ & $0.6 \pm 0.2$ & $1.3 \pm 0.1$ & $1.5 \pm 0.03$ \\
\cline { 2 - 6 } & 12.5 & $1.6 \pm 0.1$ & $1.2 \pm .06$ & $1.1 \pm 0.2$ & $1.5 \pm 0.1$ & $1.4 \pm 0.06$ \\
\cline { 2 - 7 } & 6.25 & $1.8 \pm 0.1$ & $1.3 \pm .06$ & $1.1 \pm 0.1$ & $1.6 \pm 0.1$ & $1.4 \pm 0.05$ \\
\hline \multirow{4}{*}{ S. aureus } & Control & $1.44 \pm 0.09$ & $1.59 \pm 0.08$ & $1.26 \pm 0.1$ & $1.4 \pm 0.02$ & $1.89 \pm 0.5$ \\
\cline { 2 - 7 } & 25 & $1.1 \pm 0.2$ & $0.7 \pm 0.07$ & $0.5 \pm 0.05$ & $1.2 \pm 0.05$ & $0.7 \pm 0.2$ \\
\cline { 2 - 7 } & 12.5 & $1.2 \pm 0.05$ & $1.0 \pm 0.1$ & $0.7 \pm 0.2$ & $1.2 \pm 0.02$ & $1.6 \pm 0.1$ \\
\cline { 2 - 7 } & 6.25 & $1.4 \pm 0.03$ & $1.2 \pm 0.05$ & $0.9 \pm 0.1$ & $1.3 \pm 0.1$ & $1.9 \pm 0.2$ \\
\hline \multirow{4}{*}{ E. coli } & Control & $1.45 \pm 0.8$ & $0.98 \pm 0.4$ & $0.88 \pm 0.2$ & $1.56 \pm 0.4$ & $1.12 \pm 0.8$ \\
\cline { 2 - 7 } & 25 & $0.8 \pm 0.3$ & $0.7 \pm 0.4$ & $0.6 \pm 0.1$ & $1.2 \pm 0.1$ & $0.9 \pm 0.1$ \\
\cline { 2 - 7 } & 12.5 & $1.2 \pm 0.3$ & $0.5 \pm 0.1$ & $0.7 \pm 0.1$ & $1.5 \pm 0.1$ & $1.0 \pm 0.1$ \\
\cline { 2 - 7 } & 6.25 & $1.4 \pm 0.2$ & $0.7 \pm 0.2$ & $0.8 \pm 0.1$ & $1.5 \pm 0.1$ & $0.8 \pm 0.1$ \\
\hline \multirow{3}{*}{ faecalis } & Control & $1.89 \pm 0.7$ & $0.87 \pm 0.5$ & $0.71 \pm 0.3$ & $1.69 \pm 0.4$ & $1.56 \pm 0.8$ \\
\cline { 2 - 7 } & 25 & $1.6 \pm 0.1$ & $0.5 \pm 0.1$ & $0.6 \pm 0.2$ & $1.3 \pm 0.1$ & $1.4 \pm 0.1$ \\
\cline { 2 - 7 } & 12.5 & $1.3 \pm 0.1$ & $1.4 \pm .03$ & $0.7 \pm 0.4$ & $1.5 \pm .1$ & $1.5 \pm 0.1$ \\
\hline
\end{tabular}

Table 5: Minimal inhibitory concentrations (MIC) in $\mathrm{mg} / \mathrm{ml}$ of $S$. littoralis larval extracts.

\begin{tabular}{|c|c|c|c|c|c|}
\hline Bacterial strain & Petroleum ether & Ethyl acetate & Ethanol & Methanol & Chloroform \\
\hline B. subtilis & 12.5 & 12.5 & 25 & 12.5 & 6.25 \\
\hline S. aureus & 12.5 & 6.25 & 6.25 & 6.25 & 12.5 \\
\hline E. coli & 12.5 & 6.25 & 12.5 & 25 & 6.25 \\
\hline E. faecalis & 6.25 & 25 & 12.5 & 12.5 & 25 \\
\hline
\end{tabular}

Table 6: Minimal inhibitory concentrations (MIC) in $\mathrm{mg} / \mathrm{ml}$ of $S$. littoralis larval extracts.

\begin{tabular}{|c|c|c|c|c|c|}
\hline Bacterial strain & Petroleum ether & Ethyl acetate & Ethanol & Methanol & Chloroform \\
\hline B. subtilis & 12.5 & 12.5 & 25 & 12.5 & 6.25 \\
\hline S. aureus & 12.5 & 6.25 & 6.25 & 6.25 & 12.5 \\
\hline E. coli & 12.5 & 6.25 & 12.5 & 25 & 6.25 \\
\hline E. faecalis & 6.25 & 25 & 12.5 & 12.5 & 25 \\
\hline
\end{tabular}

Table 7: Antiviral activity of $R$. ferrugineus and $S$. littoralis larval Ethyl acetate extracts.

\begin{tabular}{|c|c|c|c|c|c|c|}
\hline Extract & Dil. (mg/ml) & O D & Viability & Toxicity & Viral activity \% & Anti-viral effect \% \\
\hline Control Vero & --- & 0.217 & 100.0 & 0.0 & --- & -- \\
\hline HAV & --- & 0.127 & 58.52535 & 41.47465 & 100.0 & 0.0 \\
\hline R. ferrugineus & 625 & 0.131667 & 60.67588 & 39.32412 & 94.81482 & 5.1851751 \\
\hline S. littoralis & 312.5 & 0.130667 & 60.21505 & 39.78495 & 95.92594 & 4.0740639 \\
\hline coxB4 & --- & 0.107333 & 49.46237 & 50.53763 & 100.0 & 0.0 \\
\hline R. ferrugineus & 625 & 0.106 & 48.84793 & 51.15207 & 101.2158 & 0.0 \\
\hline S. littoralis & 312.5 & 0.106667 & 49.15515 & 50.84485 & 100.6079 & 0.0 \\
\hline HSV1 & --- & 0.117667 & 54.22427 & 45.77573 & 100.0 & 0.0 \\
\hline R. ferrugineus & 625 & 0.13 & 59.90783 & 40.09217 & 87.58389 & 12.416108 \\
\hline S. littoralis & 312.5 & 0.143667 & 66.20584 & 33.79416 & 73.8255 & 26.174497 \\
\hline
\end{tabular}

\section{Discussion}

In the present study, extracts from the larvae of Rhynchophorus ferrugineus and Spodoptera littoralis exhibited variable antibacterial activities against Gram-positive na- mely; Bacillus subtilis and Staphylococcus aureus and Gram-negative namely; Escherichia coli and Enterobacter faecalis by two methods used.The ethyl acetate extract from $R$. ferrugineus and S. littoralis larvae caused 
the highest antibacterial activity against bacterial strains. Gram-positive bacteria strains were affected by the extracts more than the Gram-negative strains. These results agreed with Leem et al. (1999) for the saw fly, Acantholyda parki extract which have a broad antibacterial spectrum against both Gram-negative and Gram-positive bacteria. Hou et al. (2007) found that the extract of the housefly larvae at high concentration showed higher antibacterial activity against both Gram- positive and Gram- negative bacteria. They concluded that extract housefly possess wide broad antibacterial activity against Gram- positive and Gram- negative bacteria. This agreed with the present study. In spite of such a response, the susceptible insects within the host range of a given pathogen were killed by the pathogen. However, insect resistant against pathogen was out of the host range (Yamauchi, 2001). Most of insect extracts exhibited antibacterial activity against Gram-positive and Gramnegative bacteria, the silk worm Bombyx mori (Hara and Yamakawa, 1995a; b), the European bumblebee, Bombus pascuorum (Rees et al, 1997) and Tenebrio molitor larvae (Lee et al, 1998). But, some insects showed activity only against Gram-positive bacteria as Aedes aegypti (Lowenberger et al, 1995), Chironomus plumosus (Lauth et al, 1998) and Anopheles gambiae (Vizioli et $a l, 2001)$.

In the present study, ethyl acetate extracts of $R$. ferrugineus and $S$. littoralis larvae displayed a variable effect on Hepatitis A virus (HAV), and Herpes simplex virus (HSV-1) Vero cell lines. But, these extracts showed no antiviral activity against Coxsackie B virus (Cox B4). These results are in agreement with such results recorded by many authors for using different insect materials against different Vero cell lines. Esser et al. (1979) proved that treatment of murine virus capsid with melittin, the viral membrane peeled off the surface, generating membrane that could be stabilized by melittin and prevent virus cell entry. Baier et al. (2000) found that the nasal application of lipopeptide increased protection against a lethal influenza infection. Wachinger et al. (1998) found that the reduction of viral infectivity was not due to an effect of melittin on virus particles but due to the peptide intracellular action of readily taken up into the cells. Fenard et al. (2001) reported that the honeybee venom phospholipase $\mathrm{A}_{2}$ (p3bv) peptide (amino acids 21 to 35 of bvPLA ${ }_{2}$ ) inhibited the replication of T-lymphotropic (T-tropic) HIV-1 isolates $\left(\mathrm{ID}_{50}=2 \mathrm{mM}\right)$ but without effect on monocytotropic (M-tropic) HIV-1 isolates. P3bv was capable to prevent cell-cell fusion process mediated by T-tropic HIV-1 envelope. Chernysh et al. (2002) isolated alloferon from wild-type of Calliphora vicina and reported that the activity spectrum of alloferon as an antiviral agent was not restricted to influenza viruses. Wu et al. (2017) stated that naturally derived phenolic acids especially caffeic acid/gallic acid and their derivatives might be regarded as novel promising antiviral leads or candidates. They added that scarcely any of these compounds was used as antiviral treatment in clinical practice. Thus, these phenolic acids with diverse skeletons and mechanisms gave an excellent resource for finding novel antiviral drugs.

In the present study, crude extracts of $R$. ferrugineus and $S$. littoralis evoked a slight effect on (CCL-81) Vero lineage. These results agreed with Nakajima and Natori (1990) and Itoh et al. (1986) for lectin from Sarcophaga larvae hemolymph induced cytotoxic effects on tumor cells in the presence of murine macrophage (Ahn et al, 2000) for the buffer, methanol and ethylacetate extracts from 26 insects against Human cervical carcinoma cell line (HELA) where, the buffer extracts from Gryllotalpa orientalis and Apriona germari larvae showed greater/more rapid (HELA) cell growth than that of other insects; (Yoo et al, 2007) for isolated (F-2, F-4, F-5 \& F-7) fractions from Protaetia brevitarsis larva, where all fractions induce apoptosis activity against Colon 26 murine carcinoma cells, Januszanis et al. 
(2012) for Galleria mellonella hemolymph polypeptides on human brain glioblastoma multiforme cell line (T98G), treated the cells with G. mellonella polypeptides inducted cell death; Kustiawan et al., (2015) for Sting less Bee Trigona incisa Propolis against human cancer derived cell lines, $\mathrm{IC}_{50}$ was $4.51 \pm 0.76 \mu \mathrm{g} / \mathrm{ml}$ against human colon cancer (SW620), $6.06 \pm 0.39 \mu \mathrm{g} / \mathrm{ml}$ against human gastric cancer (KATOIII), $0.71 \pm 0.22 \mu \mathrm{g} / \mathrm{ml}$ against human liver cancer (Hep-G2), $0.81 \pm 0.18 \mu \mathrm{g} / \mathrm{ml}$ against human lung cancer (Chago) and $4.28 \pm 0.14 \mu \mathrm{g} / \mathrm{ml}$ against human breast cancer (BT474) cell lines. In the same line, Shehata et al. (2016) found that Lucilia sericata and Chrysomya albiceps maggots excretion/secretion (ES) gave anticancer activity against seven human tumor cell lines: liver carcinoma cell line (HepG-2), breast carcinoma cell line (MCF-7), colon carcinoma cell line (HCT-116), lung carcinoma cell line (A-549), intestinal carcinoma cell line (CACO), prostate carcinoma cell line (PC-3) and cervical carcinoma cell line (HELA) with $\mathrm{IC}_{50}$ values: $14.8 \pm 0.05,31.3 \pm 0.09,27.3$ $\pm 0.11, \quad 16.4 \pm 0.07, \quad 31.1 \pm 0.31, \quad 30.4 \pm 0.12$, $85.6 \pm 0.35 \mu \mathrm{g} / \mathrm{ml}$ for L. sericata ES \& $17.3 \pm$ $0.26,33.4 \pm 0.17,32.1 \pm 0.37,20.2 \pm 0.14,34.8$ $\pm 0.25,77.6 \pm 0.19 \& 89.5 \pm 0.34 \mu \mathrm{g} / \mathrm{ml}$ for $C$. albiceps ES against (HepG-2), (MCF-7), (HCT-116), (A-549), (CACO), (PC-3), and (HELA) cell lines.

\section{Conclusion}

Emerging and reemerging viral infections represent a major concern to man and domestic animals and there is an urgent need for the development of broad-spectrum antivirals

Petroleum ether, ethyl acetate, ethanol, methanol and chloroform extracts from the palm weevil, Rhynchophorus ferrugineus and cotton leaf worm, Spodoptera littoralis larvae gave variable antibacterial activities against Gram-positive and Gram-negative bacterial strains, as well as antiviral activity against hepatitis A virus and Herpes simplex virus (HSV-1).

\section{References}

Abu-Shanab, B, Adwan, G, Abu-Safiya, D, Jarrar, N, Adwan, K, 2004: Antibacterial activities of some plant extracts utilized in popular medicine in Palestine. Turk. J. Biol. 28, 1:99102.

Armitage, P, 1974: Paired student t-test in statistical methods in medical research black well scientific pub. Oxford, London.pp:116-20.

Baier, W, Masihi, N, Huber, M, Hoffmann, P, Bessler, WG, 2000: Lipopeptides as immune adjuvants and immune stimulants in mucosal immunization. J. Immun. Biol. 201, 3/4:391405.

Boman, HG, 2003: Antibacterial peptides: basic facts and emerging concepts. J. Int. Med. 254: 197-215.

Bulet, P, Stocklin, R, Menin, L, 2004. Antimicrobial peptides: from invertebrates to vertebrates. Immunol. Rev. 198:169- 84.

Chernysh, S, Kim, SI, Bekker, G, Pleskach, V A, Filatova, NA, et al, 2002: Antiviral and antitumor peptides from insects. JABS 99, 20: 12628-32.

Cociancich, S, Dupont, A, Hegy, G, Lanot, R, Holder, F, et al, 1994: Novel inducible antibacterial peptides from a hemipteran insect, the sapsucking bug Pyrrhocoris apterus. Biochem. J. 300:567-75.

El-Sheikh, EA, Aamir, MM, 2011: Comparative effectiveness and field persistence of insect growth regulators on a field strain of the cotton leafworm, Spodoptera littoralis, Boisd (Lepidoptera: Noctuidae). Crop Protect. 30, 6:645-50. Esser, AF, Bartholomew, RM, Jensen, FC, Muiler-Eberhard, HJ, 1979: Disassembly of viral membranes by complement independent of channel formation. Proc. Nat. Acad. Sci. U.S.A., 76:5843-7.

Fehlbaum, P, Bulet P, Michaut L, Lagueux, M, Broekaert, WF, et al, 1994: Insect immunity: septic injury of Drosophila induces the synthesis of a potent antifungal peptide with sequence homology to plant antifungal peptides. J. Biol. Chem. 269: 33159-63.

Fenard, D, Lambeau, G, Maurin, T, Lefebvre, JC, Doglio, A, 2001: A peptide derived from bee venom-secreted phospholipase A2 inhibits replication of T-cell tropic HIV-1 strains via interaction with the CXCR4 chemokine receptor. Mol. Pharmacol. 60:341-7. 
Hancock, REW, Rozek, A, 2002: Role of membranes in the activities of antimicrobial cationic peptides.FEMS Microbiol. Lett. 206:143-9.

Hara, S, Yamakawa, M, 1995a: A novel antibacterial peptide family isolated from the silkworm, Bombyx mori. Biochem. J. 310, 2:651-5.

Hara, S, Yamakawa, M, 1995b: Moricin, a novel type of antibacterial peptide isolated from the silk worm, Bombyx mori. J. Biol. Chem. 270, 50:29923-27.

Hoffmann, JA, Reichhart, JM, Hetru, C, 1996: Innate immunity in higher insects. Curr. Opin. Immunol. 8:8-13.

Hou, L, Shi, Y, Zhai, P, Le, G, 2007: Antibacterial activity and in vitro anti-tumor activity of the extract o the larvae of the housefly (Musca domestica) J. Ethnoph. 111:227-31.

Hultmark, D, 1993: Immune reactions in Drosophila and other insect: Amodel for innate immunity. Tren.Genet. 9:178-83.

Irith, W, Kai, H, Hancock REW, 2008: Agar and broth dilution methods to determine the minimal inhibitory concentration (MIC) of antimicrobial substances, Nature Protocols 3, 2: 163-75.

Itoh, A, Ohsawa, E, Ohkuma, Y, Natori, S, 1986: Participation of tumor killing factor in the antitumor effect of Sarcophaga lectin. FEBS. Lett. 20:137-40.

Januszanis, B, Staczek, S, Barabas, AZ, Badziul, D, Gil, JJ, et $\boldsymbol{a l}$, 2012: Effect of Galleria mellonella hemolymph polypeptides on human brain Glioblastoma multiforme cell line- a preliminary study. Ann. UMCS, Biol. 67, 2:53-62.

Kustiawan, PA, Phuwapraisirisan, P, Puthong, S, Palaga, T, Arung, ET, et al, 2015: Propolis from the Stingless Bee Trigona incisa from East Kalimantan, Indonesia, induces in vitro cytotoxicity and apoptosis in cancer cell lines. Asian Pac. J. Cancer Prev. 16, 15:6581-9.

Lamberty, M, Ades, S, Joseph, US, Brookhart, G, Bushey, D, et al, 1999: Insect Immunity: Isolation from the lepidopteran Heliothes virescense of a novel insect defensin with potent antifungal activity. J. Biol. Chem. 274, 14:9320-6.

Lauth, X, Nesin, A, Briiand, JP, Roussel, JP, Hetru, C, 1998: Isolation, characterization and chemical synthesis of a new insect defensin from Chironomus plumosus (Diptera).Insect Biochem. Mol. Biol. 28, 12:1059-66.

Lee, KH, Hog, SY, Oh, JE, Kwon, M, Yoon, JH, et al, 1998: Identification and characterization of the antimicrobial peptide corresponding to C- terminal beta-sheet domain of tenecin 1 , an antibacterial protein of larvae of Tenebrio molitor. Biochem. J. 334:99-105.

Leem, JY, Jeong, IJ, Prak, KT, Park, HY, 1999: Isolation of P-hydroxycinnamaldehyde as an antibacterial substance from the saw fly, Acantholyda Parki S. FEBS Lett: 442:53-6.

Levashina, EA, Ohresser, S, Bulet, P, Reichhart, JM, Hetru, C, et al, 1995: Metchinikowin, a nobel immune-inducible proline- rich peptide from Drosophila with antibacterial and antifungal properties Eur. J. Biochem. 233: 694-700.

Lowenberger, C, Bulet, P, Charlet, M, Hetru, C, Hodgeman, B, et al, 1995: Insect immunity: Isolation of three noel inducible antibacterial defensins from the vector mosquito, Aedes egyp$t i$. Insect Biochem. Mol. Biol. 25, 7:867-73.

Meylears, K, Cerstiaens, A, Vierstraete, E, Baggerman, G, Michiels, CW, et al, 2002: Antimicrobial compounds of low molecular mass are constitutively present in insects: Characterisation of $\beta$-Alanyl-Tyrosine. Curr. Pharma. Design 8: 99-110.

Nakajima, Y, Natori, S, 1990: Anti-tumor factor in insect' hemolymph. Hum. Cell 3:131-6.

Netzker, T, Flak, M, Krespach, MK, Str-oe, MC, Weber, J, et al, 2018: Microbial interactions trigger the production of antibiotics. Curr. Opin. Microbiol. 45:117-23.

Rees, JA, Moniatte, M, Bulet, P, 1997: Novel antibacterial peptides isolated from a European Bumblebee Bumbus pascurum (Hymenoptera, Apoidea). Insect Bioch. Mol. Biol. 27, 5:413-22. Shahina, F, Salma, J, Mehreen, G, Bhatti, M I, Tabassum, KA, 2009: Rearing of Rhynchophorus ferrugineus in laboratory and field conditions for carrying out various efficacy studies using epns. Pak. J. Nematol. 27, 2:219-28. Shehata, AZI, Mehany, ABM, El-Sheikh, TM Y, 2016: Excretion/secretion of Lucilia sericata and Chrysomya albiceps (Diptera: Calliphoridae) maggots as potential anticancer agent and kinases inhibitor. New York Sci. J. 9, 12:95-101. Teh, CH, Nazni, WA, Nurulhusna, AH, Norazah A, Lee, HL, 2017: Determination of antibacterial activity and minimum inhibitory concentration of larval extract of fly via resazurinbased turbidometric assay. BMC. Microbiol. 17, 1:36-42.

Valgas, C, de Souza, SM, Smania, EFA, Smania, AJr, 2007: Screening methods to determine antibacterial activity of natural products. Braz. J. Microbiol. 38, 2:369-80. 
Vizioli, J, Richman, A, Joseph, US, Blass, C, Bulet, P, 2001: The defensin peptide of the malaria vector mosquito Anopheles gambiae: antimicrobial activities and expression in adult mosquitoes- Insect Biochem. Mol. Biol. 31:241-8.

Wachinger, M, Kleinschmidt, A, Winder, D, von Pechmann, N, Ludvigsen, A, et al, 1998: Antimicrobial peptides melittin and cecropin inhibit replication of human immunodeficiency virus 1 by suppressing viral gene expression. J. Gen. Virol. 79:731-40.

Wu, YH, Zhang, BY, Qiu, LP, Guan, RF, Ye, ZH, et al, 2017: Structure properties and mechanisms of action of naturally originated phenolic acids and their derivatives against human viral infections. Curr. Med. Chem. 24, 38: 4279-302.

Yamauchi, H, 2001: Two novel insect defensins from larvae of the cupreous chafer, Anomala cuprea: purification, amino acid sequences and antibacterial activity. Insect Biochem. Mol. Biol. 32:75-84.

Yoo, YC, Shin, BH, Hong, JH, Lee, J, et al, 2007: Isolation of fatty acids with anticancer activity from Protaetia brevitarsis Larva. Arch Pharm Res.30, 3:361-5.

Zasloff, M, 2002: Antimicrobial peptide of multicellular organisms. Nature 415: 389-95.

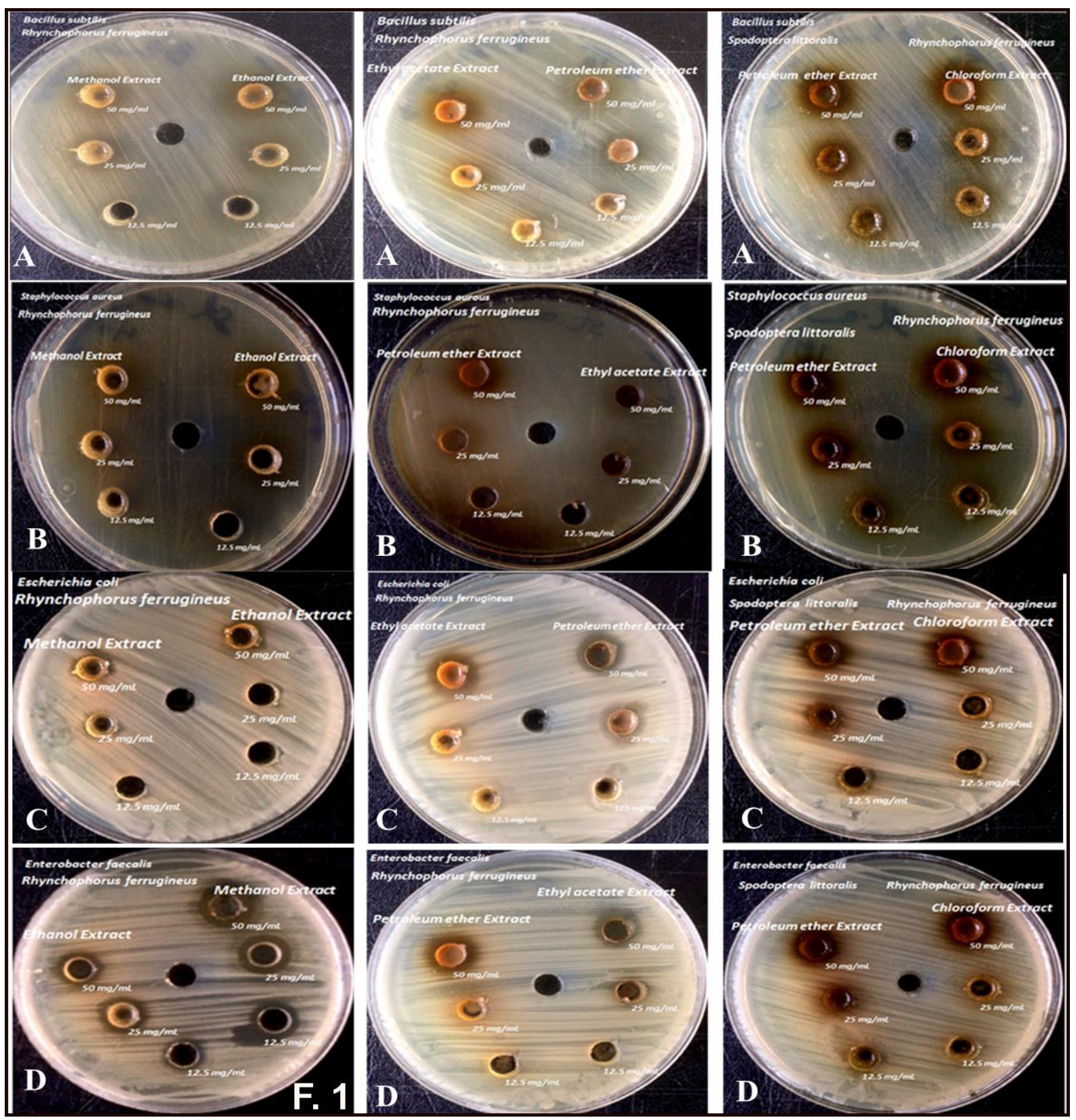

Fig. 1: Effect of R. ferrugineus larval extracts against Gram-positive and Gram-negative bacteria (A) Bacillus subtilis. (B) Staphylococcus aureus. (C) Escherichia coli. (D) Enterobacter faecalis represented by inhibition zone (mm). 


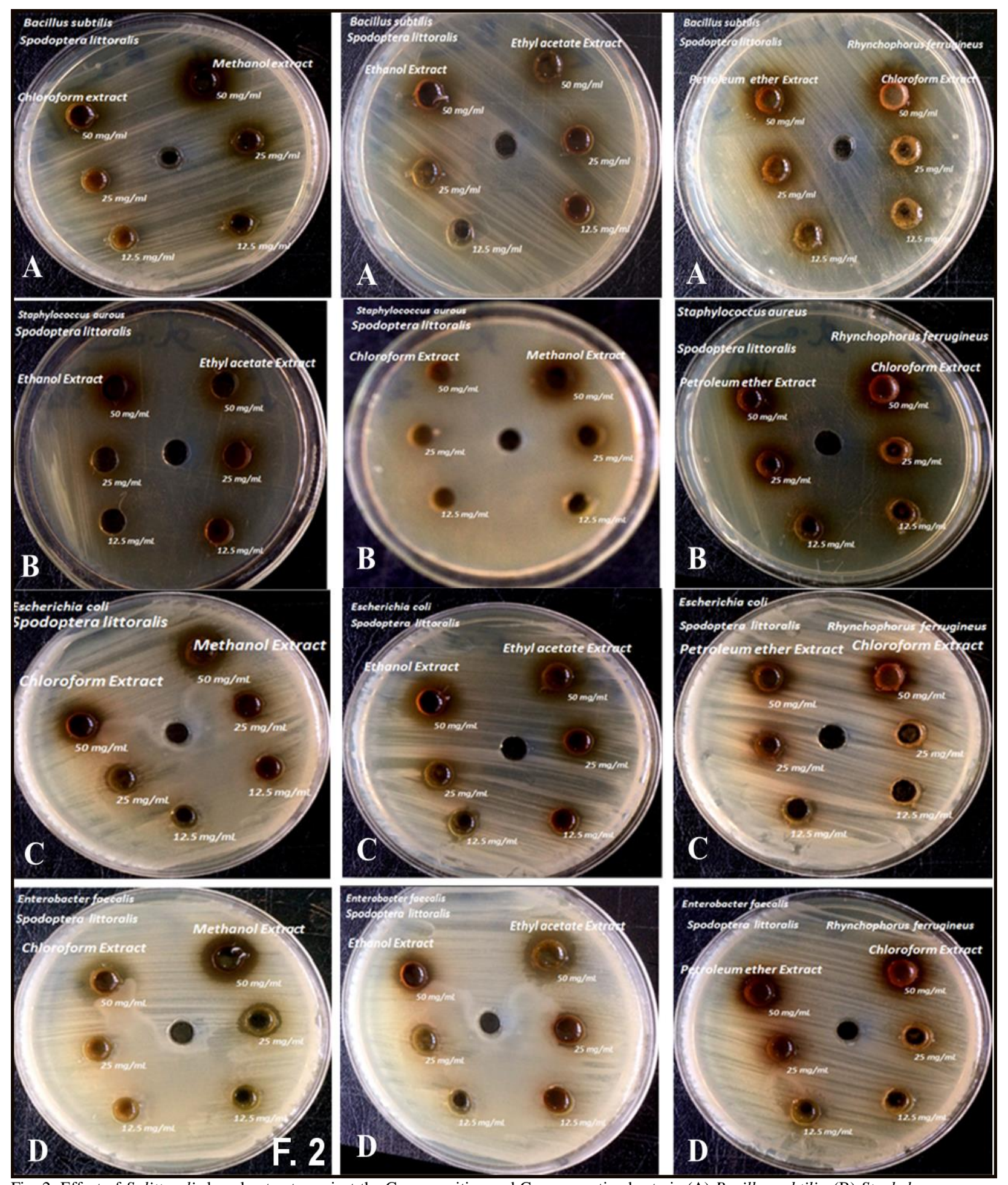

Fig. 2: Effect of S. littoralis larval extracts against the Gram-positive and Gram-negative bacteria (A) Bacillus subtilis. (B) Staphylococcus aureus. (C) Escherichia coli. (D) Enterobacter faecalis represented by inhibition zone (mm). 


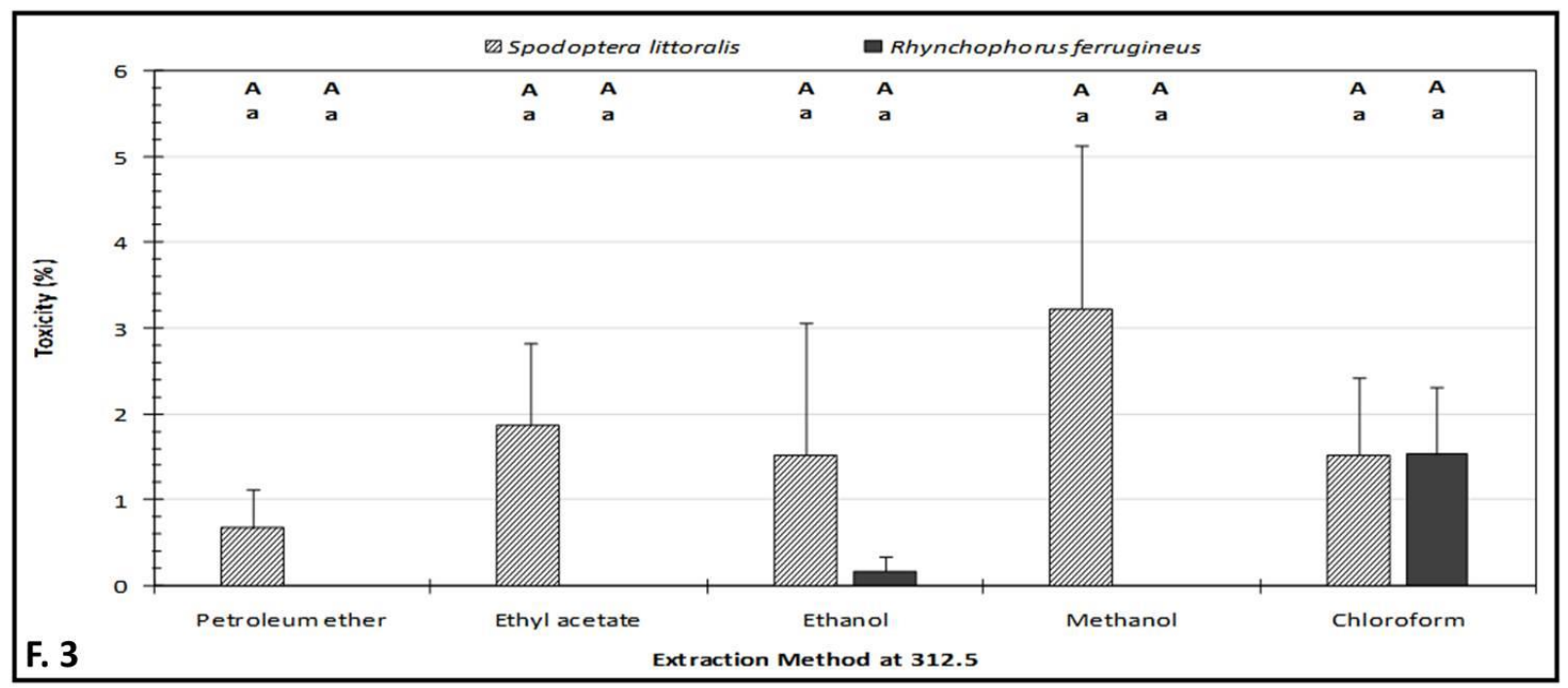

Fig. 3: Cytotoxicity assay of Vero cells in different crude extracts of $S$. littoralis and $R$. ferrugineus larvae at $312.5 \mu \mathrm{m} / \mathrm{mL}$ concentration. Capital letters represent comparisons between extracting methods.

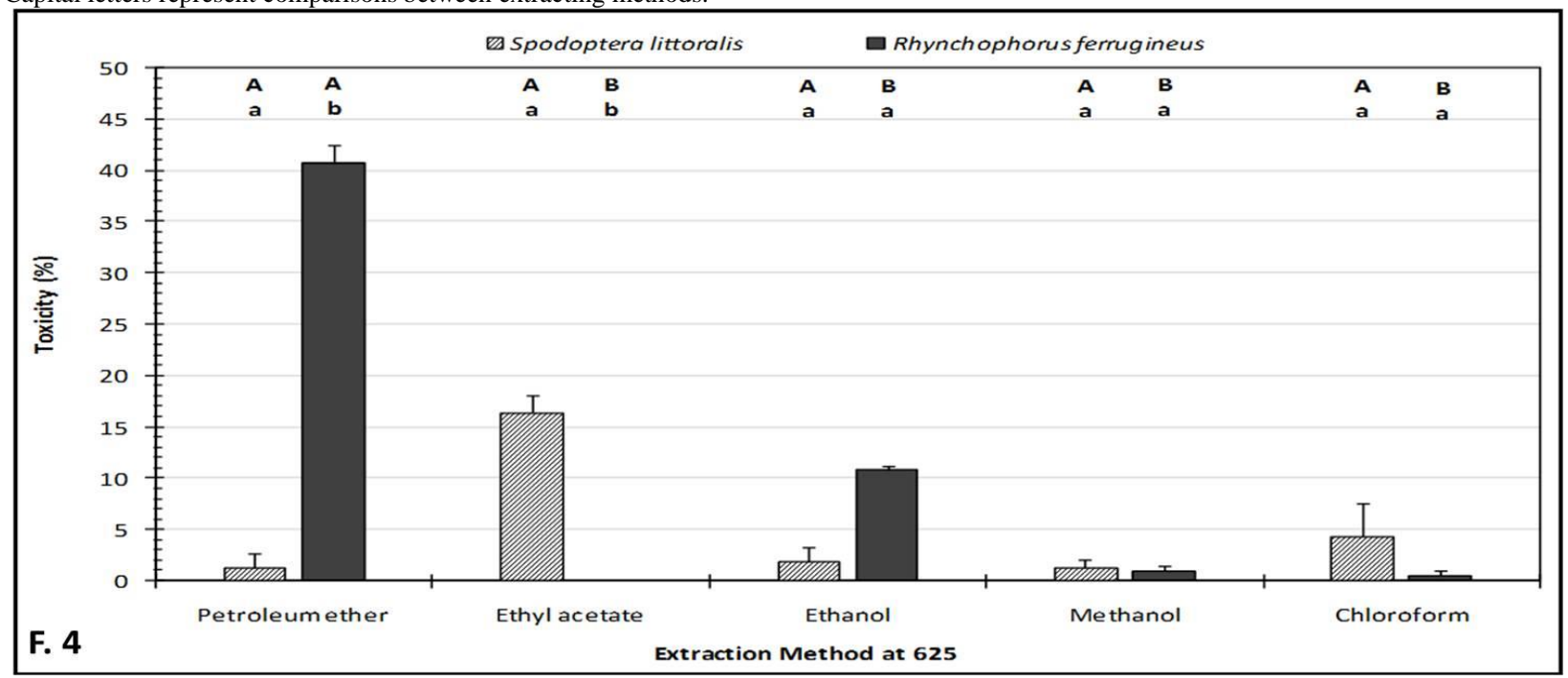

Fig. 4: Cytotoxicity assay of Vero cells in different crude extracts of $S$. littoralis and $R$. ferrugineus larvae at $625 \mu \mathrm{g} / \mathrm{mL}$ concentration. Capital letters represent comparisons between extracting methods. 